\title{
EKSISTENSI GRASI MENURUT PERSPEKTIF HUKUM PIDANA
}

\author{
Chaerul Risal \\ Universitas Islam Negeri (UIN) Makassar \\ Email : chaerulrisal@gmail.com
}

\begin{abstract}
Pardon is a form of amnesty in the form of change, mitigation, abolition or elimination of criminal practice to the convict provided by the President. The powers of the President grant pardons related to criminal law in a subjective sense. The subjective criminal law discusses the right of the state to impose and execute the criminal. The right of such a state is a great state right, so it is necessary to find the basis of its foothold through the theory of punishment. The President in granting pardons should be based on the theory of punishment.
\end{abstract}

Keywords: Grasi, Authority of the President

\begin{abstract}
Abstrak
Grasi merupakan suatu bentuk pengampunan berupa perubahan, peringanan, pengurangan, atau penghapusan pelaksanaan pidana kepada terpidana yang diberikan oleh Presiden. Kewenangan Presiden memberikan grasi terkait dengan hukum pidana dalam arti subyektif. Hukum pidana subyektif membahas mengenai hak negara untuk menjatuhkan dan menjalankan pidana. Hak negara yang demikian ini merupakan hak negara yang besar, sehingga perlu dicari dasar pijakannya melalui teori pemidanaan. Presiden dalam memberikan grasi harus didasarkan pada teori pemidanaan.
\end{abstract}

Kata kunci : Grasi, Kewenangan Presiden 


\section{PENDAHULUAN}

istem Pemerintahan Republik Indonesia menganut sistem Presidensial. Itu berarti Presiden dan wakil Presiden dipilih langsung oleh rakyat sebagaimana ketentuan Pasal 6A Undang-Undang Dasar Negara Republik Indonesia Tahun 1945 (UUD NRI 1945) dan tidak lagi oleh Majelis Permusyawaratan Rakyat (MPR) ${ }^{1}$. Dalam sistem Pemerintahan Presidensial ini terdapat hak prerogatif Presiden sebagai Kepala Negara dan Kepala Pemerintahan. Namun, karena kuatnya otoritas yang dimiliki Presiden, timbul persoalan sehingga kecenderungan terlalu kuatnya otoritas dan kekuasaan di tangan Presiden diusahakan untuk dibatasi.

Pembatasan kekuasaan Presiden tersebut dilakukan dengan adanya Perubahan terhadap UUD NRI 1945, dimana salah satu perubahan itu terjadi pada kekuasaan Presiden di bidang yudisial, berkaitan dengan kewenangan Presiden dalam pemberian Grasi. Grasi sebenarnya bukanlah upaya hukum, namun merupakan hak Kepala Negara untuk memberikan pengampunan kepada warganya yang dijatuhi putusan oleh pengadilan. Pemberian Grasi oleh Presiden selaku Kepala Negara bukan sebagai Kepala Pemerintahan (eksekutif) atau yudikatif, tetapi merupakan hak prerogatif Presiden untuk memberikan pengampunan.

Di negara dengan tingkat keanekaragaman penduduknya yang luas seperti Indonesia, sistem presidensial ini efektif untuk menjamin sistem pemerintahan yang kuat dan efektif. Kuatnya otoritas yang dimilikinya, timbul persoalan berkenaan dengan dinamika demokrasi ${ }^{2}$. Perubahan Undang-undang Dasar 1945, kelemahan sistem presidensial seperti kecenderungan terlalu kuatnya otoritas dan konsentrasi kekuasaan di tangan presiden, diusahakan untuk dibatasi.

Ketentuan Pasal 14 UUD 1945 sebelum perubahan, Presiden mempunyai kewenangan untuk memberikan Grasi, Amnesti, Abolisi, dan Rehabilitasi. Setelah perubahan UUD 1945 yang pertama, ketentuan tersebut sedikit mengalami perubahan, yaitu dalam hal memberi Grasi dan Rehabilitasi, Presiden memperhatikan pertimbangan Mahkamah Agung dan dalam hal memberi Amnesti dan Abolisi, Presiden memperhatikan pertimbangan $\mathrm{DPR}^{3}$." Setiap

\footnotetext{
${ }^{1}$ Sahetapy J.E, 2007, Yang Memberi Tauladan Dan Menjaga Nurani Hukum \& Politik, Jakarta, Komisi Hukum Nasional RI, hlm 320

${ }^{2}$ Ibid, h.164

${ }^{3}$ Abdul Ghofar, Perbandingan Kekuasaan Presiden Indonesia Setelah Perubahan UUD 1945 Dengan Delapan Negara Maju, Jakarta: kencana, 2009, h. 104
} 
permohonan Grasi harus disertai dengan pertimbangan Mahkamah Agung karena Grasi mengenai atau menyangkut putusan hakim. ${ }^{4}$

Undang-Undang Nomor 22 Tahun 2002 tentang Grasi merupakan pengganti dari Undang-Undang Nomor 3 Tahun 1950 tentang Permohonan Grasi yang dibentuk pada masa pemerintahan Republik Indonesia Serikat, sehingga saat ini tidak sesuai lagi dengan sistem ketatanegaraan Indonesia dan substansinya sudah tidak sesuai lagi dengan perkembangan kebutuhan tata hukum Indonesia. ${ }^{5}$

Pada Pasal 1 Undang-Undang Nomor 22 Tahun 2002 tentang Grasi: "Grasi adalah pengampunan berupa perubahan, peringanan, pengurangan, atau penghapusan pelaksanaan pidana kepada terpidana yang diberikan oleh Presiden." Penjelasan undang-undang tersebut dikatakan, pemberian Grasi dapat merubah, meringankan, mengurangi atau menghapuskan kewajiban menjalani pidana yang dijatuhkan pengadilan. Hal ini tidak berarti menghilangkan kesalahan dan juga bukan merupakan rehabilitasi terhadap pidana.

Kewenangan Presiden memberikan grasi terkait dengan hukum pidana dalam arti subyektif. Hukum pidana subyektif membahas mengenai hak negara untuk menjatuhkan dan menjalankan pidana. Hak negara yang demikian ini merupakan hak negara yang besar, sehingga perlu dicari dasar pijakannya melalui teori pemidanaan. Presiden dalam memberikan grasi harus didasarkan pada teori pemidanaan.

Terkait dengan masalah grasi ini, sejak pertengahan tahun 2003 lalu presiden Megawati Soekarnoputri menolak permohonan grasi enam terpidana mati. Mereka adalah lima orang terlibat pembunuhan, dan satu orang dalam kasus narkoba. Pemberian grasi pada masa Orde Baru bukan suatu hal yang baru. Grasi berupa perubahan status terpidana mati menjadi seumur hidup, pernah diberikan kepada Soebandrio dan Omar Dhani. Demikian pula terhadap sembilan terpidana lain (1980), setelah itu, tidak kurang dari 101 permohonan grasi diberikan oleh presiden Soeharto. Tentu saja hal ini bukanlah jumlah yang sedikit, mengingat kekuasaan Orde Baru telah bertengger selama 32 tahun.

Beberapa resiko yang dikhawatirkan sebagai akibat dari vonis yang dijatuhkan oleh hakim, khususnya untuk pidana maksimal seperti pidana mati, yaitu adanya kemungkinan terjadi eksekusi terhadap innocent people. Adanya kekhilafan dalam proses hukum, meliputi proses penuntutan, penangkapan yang salah, atau keterangan dari saksi yang tidak dapat dipercaya, bisa saja terjadi.

${ }^{4}$ Bagir Manan, Lembaga Kepresidenan, Yogyakarta: FH UII Press, 2003, hlm 161

${ }^{5}$ Lihat Penjelasan Umum Undang-Undang Nomor 22 tahun 2002 tentang Grasi. 
Kata lain, grasi merupakan salah satu lembaga yang bisa mengkoreksi dan mengatasi resiko tersebut. Itulah sebabnya mengapa grasi berada di luar lingkup peradilan pidana. Hal ini memberikan indikasi bahwa, meskipun grasi merupakan kewenangan presiden yang berada dalam lingkup Hukum Tata Negara, hukum pidana juga memandang tentang keberadaan grasi dalam hal upaya dari terpidana untuk menghindarkan dari eksekusi putusan.

\section{PEMBAHASAN}

\section{A. Aturan Hukum Pemberian Grasi di Indonesia}

Permohonan grasi ini diajukan oleh yang dihukum bersalah kepada kepala negara atau presiden yang kedudukannya sebagai Kepala Negara yang mempunyai hak prerogatif. Pemberian grasi merupakan suatu hak, maka kepala negara tidak berkewajiban untuk mengabulkan semua permohonan grasi yang ditujukan kepadanya. Kedudukannya sebagai Kepala Negara, maka walaupun ada nasihat atau pertimbangan dari Mahkamah Agung, Grasi oleh Presiden pada dasarnya adalah bukan suatu tindakan hukum, melainkan suatu tindakan nonhukum berdasarkan hak preogratif seorang Kepala Negara. Dengan demikian Grasi bersifat pengampunan berupa mengurangi pidana (starfverminderend) atau memperingan pidana atau penghapusan pelaksanaan pidana yang telah diputuskan oleh Mahkamah Agung. Bisa juga Grasi itu ditolak oleh Presiden. Pemberian grasi oleh kepala negara kepada si terhukum pada umumnya dilatarbelakangi oleh hal-hal sebagai berikut;

a. Seandainya dipandang adanya kekuranglayakan dalam penerapan hukum, maka pemberian grasi dalam hal ini adalah untuk memperbaiki penerapan hukum;

b. Seandainya dipandang bahwa para terhukum sangat dibutuhkan negara atau pada mereka terdapat penyesalan yang sangat mendalam, maka dalam hal ini pemberian grasi adalah demi kepentingan negara.

Pertimbangan pemberian grasi kepada si terhukum lebih dititikberatkan pada memberi penilaian kembali terhadap putusan hakim. Putusan tersebut dinilai kembali apakah putusan tersebut telah sesuai dengan kesalahan yang terbukti dilakukan oleh si terhukum atau apakah putusan tersebut ternyata terlalu berat dibandingkan dengan keadaan atau situasi pada saat putusan tersebut dijatuhkan. Pemberian grasi merupakan suatu koreksi atas putusan hakim dengan dasar alasan-alasan yang telah diketahui setelah hakim menjatuhkan putusannya.

Undang-undang Nomor 3 Tahun 1950 tentang Permohonan Grasi (UU Permohonan Grasi), tidak disebutkan secara jelas mengenai pengertian grasi. 
Namun, pengertian grasi dapat kita simpulkan dari pasal 1 UU Permohonan Grasi yang berbunyi; "Atas hukuman-hukuman yang dijatuhkan oleh keputusan kehakiman, baik militer maupun sipil yang tidak dapat diubah lagi, orang yang dihukum atau pihak lain dapat memajukan permohonan grasi kepada Presiden." Sebelum tahun 2002, pemberian grasi didasarkan pada Undangundang Nomor 3 Tahun 1950 tentang Permohonan Grasi (Lembaran Negara Tahun 1950 Nomor 40) yang dikeluarkan pada masa Republik Indonesia Serikat, mengatur prosedur yang melibatkan beberapa instansi terkait, termasuk Mahkamah Agung yang diberi kewenangan untuk memberikan pertimbangan permohonan grasi.

Berdasarkan bunyi pasal tersebut, dapat disimpulkan bahwa grasi merupakan pengampunan yang dapat diajukan kepada Presiden atas hukumanhukuman yang dijatuhkan kepada si terhukum. Pasal 1 Undang-undang Nomor 22 Tahun 2002 tentang Grasi (UU Grasi) memberikan pengertian mengenai grasi yaitu sebagai pengampunan berupa perubahan, peringanan, pengurangan, atau penghapusan pelaksanaan pidana kepada terpidana yang diberikan oleh Presiden. Pada penjelasan pasal 2 UU Grasi dinyatakan bahwa putusan pengadilan yang dapat dimintakan grasi adalah putusan pengadilan sipil atau putusan pengadilan militer. Dengan demikian tidak ada perubahan yang menonjol dalam pengertian grasi menurut kedua UU tersebut. Grasi, pada dasarnya, pemberian dari Presiden dalam bentuk pengampunan yang berupa perubahan, peringanan, pengurangan, atau penghapusan pelaksanaan putusan.

Pengajuan Grasi telah diatur prosedurnya berdasarkan Undang-Undang Republik Indonesia No. 22 Tahun 2002 Tentang Grasi, prosedur permohonan grasi yaitu sebagai berikut ${ }^{6}$;

1. Hakim atau hakim ketua sidang yang memutus perkara pada tingkat pertama memberitahukan hak mengajukan grasi kepada terpidana sesaat setelah putusan dibacakan. Namun, apabila terpidana tidak hadir, hak terpidana diberitahukan secara tertulis oleh panitera dari pengadilan yang memutus perkara pada tingkat pertama;

2. Surat permohonan yang diajukan oleh terpidana atau orang lain dengan persetujuan terpidana (dalam hal terpidana dijatuhi pidana mati, dapat diajukan tanpa persetujuan terpidana) harus diajukan kepada Presiden setelah putusan pengadilan memperoleh kekuatan hukum tetap dan disampaikan kepada Pengadilan yang memutus pada

\footnotetext{
${ }^{6}$ Pasal 5 s.d. 13 Undang-undang Republik Indonesia Nomor 22 Tahun 2002 tentang Grasi
} 
tingkat pertama untuk diteruskan kepada Mahkamah Agung. Permohonan grasi ini (dan salinannya) dapat pula disampaikan melalui Kepala Lembaga Pemasyarakatan tempat terpidana menjalani pidana yang nantinya akan disampaikan oleh Kepala Lembaga Pemasyarakatan tersebut kepada Presiden dan salinannya kepada pengadilan yang memutus perkara pada tingkat pertama;

3. Permohonan grasi tidak dibatasi oleh tenggang waktu tertentu;

4. Setelah menerima permohonan yang diajukan, dalam jangka waktu paling lambat 20 (dua puluh) hari terhitung sejak tanggal penerimaan salinan permohonan grasi, Panitera Pengadilan mengirimkan surat permohonan tersebut beserta berita-berita acara sidang, surat putusan yang bersangkutan atau salinannya, dan banding serta kasasi (bila ada) kepada Ketua Pengadilan yang memutus pada tingkat pertama untuk diteruskan ke Mahkamah Agung;

5. Mahkamah Agung (MA) memberikan pertimbanganpertimbangannya terhadap grasi yang diajukan terpidana;

6. Dalam jangka paling lama tiga bulan terhitung sejak tanggal diterimanya salinan permohonan dan berkas perkara, MA segera meneruskan berkas-berkas tersebut beserta pertimbangan yang tertulis kepada Presiden;

7. Presiden kemudian memberikan keputusannya, apakah mengabulkan permohonan grasi atau menolaknya. Jangka waktu pemberian atau penolakan grasi paling lambat tiga bulan terhitung sejak diterimanya pertimbangan Mahkamah Agung. Kemudian Keputusan Presiden megenai grasi tersebut disampaikan kepada terpidana paling lambat empat belas hari terhitung sejak ditetapkannya Keputusan Presiden; dan

8. Salinan Keputusan Presiden (Keppres) tersebut disampaikan kepada:

a. Mahkamah Agung;

b. Pengadilan yang memutus perkara pada tingkat pertama;

c. Kejaksaan Negeri yang menuntut perkara terpidana; dan

d. Lembaga Pemasyarakatan tempat terpidana menjalani pidana terkait.

Prosedur pengajuan grasi sebagaimana telah dipaparkan diatas merupakan prosedur pengajuan grasi yang baku yang harus dilakukan oleh terpidana maupun kuasa hukumnya baik pada pengajuan grasi yang pertama maupun pengajuan grasi yang kedua. Namun untuk dapat mengajukan 
permohonan grasi yang kedua, terpidana harus menunggu waktu dua tahun sejak pengajuan grasi yang pertama ditolak oleh Presiden.

\section{B. Eksistensi Pemberian Grasi Ditinjau Dari Perspektif Hukum Pidana \\ 1. Alasan Pemberian Grasi}

Undang- undang tidak mengatur secara eksplisit yang merinci mengenai alasan dari pemberian grasi. Jan Remmelink mengemukakan alasan-alasan pemberian grasi sebagai berikut ${ }^{7}$ :

a. Jika setelah vonis berkekuatan hukum pasti terpidana menghadapi suatu keadaan khusus yang sangat tidak menguntungkan baginya. Misalnya terpidana menderita penyakit tidak tersembuhkan atau keluarganya terancam akan tercerai berai;

b. Jika setelah vonis berkekuatan hukum pasti, ternyata bahwa hakim secara tidak layak telah tidak memberi perhatian pada keadaan, yang bila ia ketahui sebelumnya, akan mengakibatkan penjatuhan pidana yang jauh lebih rendah. Patut dicermati bahwa hal ini bukanlah alasan untuk memohonkan peninjauan kembali. Terpikirkan juga sejumlah kesalahan hakim lainnya yang tidak membuka peluang bagi permohonan peninjauan kembali;

c. Jika semenjak putusan berkekuatan hukum pasti, ternyata situasi kemasyarakatan telah berubah total, misalnya deklarasi perihal situasi darurat sipil karena tiadanya pangan telah dicabut atau pandangan politik yang dulu berlaku telah mengalami perubahan mendasar;

d. Jika ternyata telah terjadi kesalahan hukum yang besar. Terbayangkan di sini putusan-putusan pengadilan terhadap para pelaku kejahatan perang, yang di periksa dan diadili setelah perang usai. Melalui grasi, putusanputusan yang nyata sangat tidak adil masih dapat diluruskan.

Grasi dalam hukum pidana, tidak hanya mengenai ampunan atau pengurangan hukuman terhadap putusan hakim saja. Kita perlu melihat grasi dari sisi lainnya, yakni grasi sebagai hak warga negara ${ }^{8}$.

Seperti telah dijelaskan sebelumnya, pemberian grasi merupakan pencabutan atau upaya meringankan sanksi yang dijatuhkan melalui putusan pengadilan pidana. Dahulu kala, penguasa beranjak dari kekuasaan mutlak yang

${ }^{7}$ Jan Remmelink, Hukum Pidana: Komentar atas Pasal-pasal dari KUHP Belanda dan Padanannya dalam KUHP Indonesia, Gramedia Pustaka, Jakarta, 2003

${ }^{8}$ Andi Hamzah, Asas-asas Hukum Pidana, Rineka Cipta, Jakarta, 1991 
dimilikinya menganugerahkan grasi sebagai wujud kebajikan hatinya. Sekarang kita tak lagi mengenal grasi dalam bentuk seperti itu, terutama karena hak prerogatif (hak istemewa) telah diserahkan kepada pemerintah dan pelaksanaannya menjadi tanggung jawab Kepala Negara atau dalam sistem pemerintahan presidensial ada di tangan presiden. Kewenangan presiden di luar lingkup eksekutif tersebut, misalnya kewenangan di bidang judisial. Kewenangan ini mencakup pemulihan yang terkait dengan putusan pengadilan, yaitu untuk mengurangi hukuman, memberikan pengampunan, ataupun menghapuskan tuntutan yang terkait erat dengan kewenangan pengadilan.

Mengenai pemberian ampunan atau grasi, perlu diketahui konsep bahwa terpidana yang mengajukan permohonan grasi ini bukan sebagai terpidana, melainkan sebagai warga negara. Sebagai seorang warga negara, seseorang berhak meminta ampun kepada presiden sebagai pemimpin negara. Pasal $28 \mathrm{D}$ ayat (1) Amandemen Undang-undang Dasar 1945 dalam sub mengenai Hak Asasi Manusia, diatur mengenai "Setiap orang berhak atas pengakuan, jaminan, perlindungan, dan kepastian hukum yang adil serta perlakuan yang sama di hadapan hukum". Inilah yang menjadi dasar setiap warga negara apapun status yang sedang disandangnya, untuk mendapatkan suatu kepastian hukum.

Pemberian grasi bukan isu kepastian hukum, tetapi cerminan tingkat kearifan hukum presiden dan juga masyarakat. Dengan adanya pertimbangan dari Mahkamah Agung, dan berbagai faktor sosial serta respon dari kelompok tertentu, pemberian grasi mencerminkan kearifan hukum dari presiden. Mungkin kita lupa bahwa pemberian grasi adalah juga tempat dimana kita memberikan tempat bagi hati nurani kemanusiaan kita.

Bagi pemohon yang dijatuhi pidana mati, grasi merupakan persoalan hidup dan mati. Melalui pemberian grasi, mungkin saja seseorang yang dijatuhi pidana mati dapat menjadi penjara seumur hidup atau pidana penjara dalam waktu tertentu. Hal seperti ini akan terasa lebih arif. Karena terpidana akan mempunyai kesempatan untuk memperbaiki dirinya. Berbeda dengan pidana mati yang tidak memberikan kesempatan bagi terpidana untuk memperbaiki kesalahannya?

${ }^{9}$ Adami Chazawi, Pelajaran Hukum Pidana Bagian II, Raja Grafindo Persada, Jakarta, 2002 


\section{Kewenangan Pemberian Grasi}

Pemberian grasi oleh Presiden kepada terpidana adalah kewenangan konstitusional sebagaimana diatur dalam UUD 1945 Pasal 14 ayat (1) dan Undang- Undang Nomor 5 Tahun 2010 tentang Perubahan Atas Undang-Undang Nomor 22 Tahun 2002 tentang Grasi. Peraturan perundang-undangan memberikan sejumlah kewenangan kepada Mahkamah Agung. Pertama, wewenang untuk memeriksa dan memutus permohonan kasasi, sengketa kewenangan mengadili, dan permohonan peninjauan kembali putusan yang telah berkekuatan hukum tetap. Kedua, wewenang menguji peraturan perundang-undangan di bawah undang-undang. Ketiga, memberikan pertimbangan terhadap permohonan grasi dan rehabilitasi.

Wewenang Mahkamah Agung memberikan pertimbangan dalam permohonan grasi sebenarnya amanat konstitusi. Pasal 14 ayat (1) UUD 1945 merumuskan "Presiden memberi grasi dan rehabilitasi dengan memperhatikan pertimbangan Mahkamah Agung”. Dalam penjelasan rumusan Pasal 14 UUD 1945 sebelum amandemen, wewenang itu dijalankan presiden selaku kepala negara. Pemberian grasi dianggap sebagai hak prerogatif presiden yang tak bisa diganggu gugat.

Pemberian grasi oleh presiden dapat berupa peringanan atau perubahan jenis pidana, pengurangan jumlah pidana, atau penghapusan pelaksanaan pidana ${ }^{10}$. Namun sebelum membuat keputusan tentang pemberian grasi, presiden harus memperhatikan pertimbangan Mahkamah Agung. Persetujuan atau penolakan permohonan grasi sepenuhnya berada di tangan presiden. Norma ini tertuang jelas dalam Pasal 4 ayat (1) UU No. 22 Tahun 2002 tentang Grasi (terakhir diubah dengan UU No. 5 Tahun 2010). Jadi, Mahkamah Agung sebatas memberikan pertimbangan hukum.

Mahkamah Agung dimaksudkan agar presiden mendapatkan masukan dari lembaga yang tepat sesuai fungsinya. Sebagai lembaga peradilan tertinggi, Mahkamah Agung adalah lembaga negara paling tepat memberikan pertimbangan kepada presiden mengenai hal itu (grasi). Pertimbangan itu juga dimaksudkan agar terjalin saling mengawasi antar lembaga negara.

Kewenangan Presiden dalam pemberian Grasi perlu memperhatikan pertimbangan dari Mahkamah Agung sebagai lembaga yudikatif, agar terjalin saling mengawasi dan saling mengimbangi antara Presiden dan kedua lembaga

${ }^{10}$ Sahetapy J.E, Yang Memberi Tauladan Dan Menjaga Nurani Hukum \& Politik,Jakarta, 2007 
negara tersebut dalam hal pelaksanaan tugas kenegaraan. Adanya peran serta pertimbangan Mahkamah Agung kepada Presiden dalam pemberian Grasi, memberikan batasan kepada Presiden dalam mengunakan kekuasaannnya sehingga dapat menghindari pemberian Grasi yang berlebihan kepada pelaku kejahatan yang berat. Kriteria yang dijadikan pertimbangan bagi Presiden dalam pemberian Grasi dan implikasi hukumnya, pertimbangan yang diberikan Presiden berdasarkan atas pertimbangan-pertimbangan lain diluar hukum, termasuk yang menyangkut pertimbangan kemanusiaan dan tetap menjunjung tinggi rasa keadilan dan kepastian hukum. Pemberian Grasi oleh Presiden menimbulkan implikasi hukum terhadap terpidana yang mengajukan permohonan Grasi. Keputusan yang diambil oleh Presiden, baik yang bersifat menolak maupun mengabulkan permohonan Grasi, tidak akan memperberat pidana yang diputus oleh pengadilan ${ }^{11}$.

Beberapa pengaturan baru dalam Undang-Undang Nomor 22 Tahun 2002 tentang Grasi yang ada dirasa lebih menjamin kepastian hukum bagi pemohon Grasi, ternyata ada satu hal yang pengaturannya tidak tegas, yaitu mengenai tidak ada pembatasan waktu bagi pemohon Grasi. Untuk putusan yang berupa pidana penjara seumur hidup, pidana penjara sementara waktu, dengan tidak adanya pembatasan waktu tersebut tidak akan berpengaruh pada pelaksanaan putusan, tetapi untuk terpidana mati eksekusinya harus menunggu putusan penolakan Grasi dari Presiden. Ketidakjelasan pengaturan tersebut dapat dimamfaatkan oleh terpidana mati untuk menunda eksekusi hukuman.

3. Keberadaan Atau Eksistensi Pemberian Grasi di Indonesia

Sesuai dengan ketentuan Pasal 14 ayat (1) UUD NRI Tahun 1945, pemberian grasi merupakan wewenang Presiden setelah mendapatkan pertimbangan MA. Pengaturan kewenangan ini selanjutnya diatur dalam UU Nomor 22 Tahun 2002 tentang Grasi. Bila ditinjau dari segi hukum tata negara, pemberian grasi merupakan kewenangan yang melekat dalam kedudukan Presiden sebagai kepala negara. Kewenangan ini secara umum dimiliki oleh kepala negara di berbagai negara. Grasi sendiri merupakan pengampunan dalam bentuk perubahan, peringanan, pengurangan atau penghapusan pelaksanaan hukuman yang diberikan oleh Presiden. Ditinjau dari segi produce of law, pemberian grasi ini tidak berarti Presiden mencampuri proses penegakan hukum karena pemberian grasi tidak berarti menghapuskan kesalahan terpidana. Pengampunan diberikan terhadap terpidana dengan alasan subjektivitas Presiden (biasanya karena alasan

${ }^{11}$ E. Utrecht, Rangkaian Sari Kuliah Hukum Pidana II, Universitas, Bandung, 1965 
kemanusiaan). Kata lain, pemberian grasi ini tidak bertentangan dengan hukum positif yang ada di negara ini alias konstitusional. Memang benar, bahwa secara hukum, pemberian grasi tersebut konstitusional. Presiden sebagai pengayom dan pelindung masyarakat harus lebih peka dengan masyarakatnya sendiri. Presiden seharusnya bisa lebih bijak dan tidak mengobral pengampunan tersebut terhadap kasus yang sangat berpengaruh negatif dalam regenerasi bangsa ini.

Pemberian grasi ini pun menjadi salah satu bukti inkonsistensi dan kealpaan Presiden terdahulu. Bahkan pada masa pemerintahan Presiden Susilo Bambang Yudhoyono (SBY) sepertinya sudah lupa dengan janjinya ketika memperingati hari Anti Narkotika Internasional yang diselenggarakan di Istana Negara, 30 Juni 2006 lalu. SBY berjanji akan berdiri paling depan dalam usaha pemberantasan narkoba dan tidak akan memberikan pengampunan berupa grasi terhadap pelaku kejahatan narkoba. Setidaknya ada dua kelalaian Presiden dalam memberikan grasi terhadap pelaku kejahatan narkoba. Pertama, pemberian grasi tersebut bertentangan dengan rekomendasi maupun pertimbangan yang diberikan MA sebagai yudikatif tertinggi di negeri ini. Pasal 14 UUD NRI Tahun 1945 dikatakan bahwa pemberian grasi harus memperhatikan pertimbangan MA. Memang, secara prosedural Presiden telah melakukan itu, namun secara substansial, Presiden gagal menangkap pesan yang diberikan MA lewat putusannya. Kendati pertimbangan MA tidak mengikat, penjatuhan pidana mati pada tingkat kasasi dan PK harusnya menjadi pertimbangan bahwa tidak ada hal meringankan yang patut dialamatkan terhadap kedua terpidana tersebut. Kedua, UU Grasi tidak mengatur pengecualian terhadap pelaku tindak pidana apa grasi bisa dilakukan. Artinya, pemberian grasi bisa saja dilakukan terhadap terpidana dalam kasus apa pun. Presiden seharusnya paham bahwa kejahatan narkoba merupakan kejahatan yang sangat berbahaya dan bersifat transnasional.

Pemberian Grasi oleh Presiden menimbulkan implikasi hukum terhadap terpidana yang mengajukan permohonan Grasi. Keputusan yang diambil oleh Presiden, baik yang bersifat menolak maupun mengabulkan permohonan Grasi, tidak akan memperberat pidana yang diputus oleh pengadilan. Terpidana yang mendapatkan Grasi akan merasakan kebebasan karena dapat keluar secepatnya dan bebas dari segala kewajiban menjalani pidana yang dijatuhkan padanya. Implikasi hukum yang paling berat diterima oleh terpidana adalah Grasinya ditolak oleh Presiden, sehingga terpidana tetap harus menjalani pidana sesuai dengan putusan pengadilan yang telah berkekuatan hukum tetap.

Alasan hak asasi manusia yang dikemukakan pemerintah patut dipertanyakan, karena dampak yang dilakukan para terpidana narkoba itu sangat hebat dalam menghancurkan dan membunuh masa depan kemanusiaan. Oleh 
karena itu, ketentuan pasal 14 ayat (1) UUD 1945 tersebut tidak dapat dimaknai sebagai hak prerogatif, namun hanya sebatas hak konstitusional. Pemberian grasi kepada pengedar narkoba, tentu saja akan menimbulkan pertanyaan di masyarakat. Letak konsistensi dari pemerintah untuk memberantas peredaran narkoba di negeri ini. Tentu saja ini akan berdampak besar terhadap penanganan masalah narkoba di tanah air. Langkah yang diambil oleh pemerintah saya anggap merupakan suatu langkah mundur. Berbagai upaya yang pernah dilakukan pemerintah dalam pemberantasan narkoba seolah-olah harus terhenti sampai di sini. Ini telah menjadi simbol adanya ruang gerak bagi pengedar narkoba baik yang berskala nasional maupun internasional.

Lembaga grasi yang menjadi ruang istimewa bagi presiden, tidak lagi dapat menafsirkan penilaian masyarakat, terutama ketika grasi dianggap mencederai kepentingan yang lebih tinggi. Pertimbangan MA andai diperhatikan oleh presiden dalam pemberian grasi ternyata tidak cukup, lebih-lebih apabila pertimbangan MA tidak diperhatikan. Kepentingan sosial, baik kesejahteraan, keamanan, ketertiban, dan kemanusiaan menjadi tuntutan untuk memaknai kembali lembaga grasi, juga rehabilitasi yang sama-sama disebut dalam pasal 14 ayat (1) UUD RI 1945. Derajat rasionalitas grasi membutuhkan aras yang lebih tinggi. Artinya, secara prosedural meskipun grasi merupakan kekuasaan presiden, tampaknya pertimbangan yang dibutuhkan tidak cukup dari MA, apalagi hanya lembaga negara di bawah kekuasan presiden. Dibutuhkan keterlibatan lembaga lain yang merepresentasikan kepentingan masyarakat sebagai sasaran kasus kejahatan.

\section{PENUTUP}

Grasi bukan merupakan upaya hukum. Meskipun grasi dapat merubah status hukuman seseorang, grasi dipandang sebagai hak prerogatif yang hanya ada di tangan Presiden. Upaya hukum hanya yang disebutkan di dalam KUHAP. Eksistensi grasi dalam perspektif hukum pidana, pemohon yang mengajukan grasi tidak sebagai terpidana melainkan sebagai warga negara yang berhak meminta ampun atas kesalahannya kepada Presiden sebagai pemimpin negara. Grasi tidak terkait dengan penilaian terhadap putusan hakim dan tidak dapat menghilangkan kesalahan terpidana. 


\section{DAFTAR PUSTAKA}

Adami Chazawi, Pelajaran Hukum Pidana Bagian II, Raja Grafindo Persada, Jakarta, 2002

Andi Hamzah, Asas-asas Hukum Pidana, Rineka Cipta, Jakarta, 1991

Bagir Manan, Lembaga Kepresidenan, Yogyakarta: FH UII Press, 2003

Bambang Purnomo, Asas-asas Hukum Pidana, Ghalia Indonesia, Terbitan Ketujuh, Jakarta,1994

E. Utrecht, Rangkaian Sari Kuliah Hukum Pidana II, Universitas, Bandung, 1965 Ismail Suny, Mekanisme Demokrasi Pancasila, Aksara Baru, Jakarta, 1981

Jan Remmelink, Hukum Pidana: Komentar atas Pasal-pasal dari KUHP Belanda dan Padanannya dalam KUHP Indonesia, Gramedia Pustaka, Jakarta, 2003

Jimly Ashiddiqe, Konstitusi dan Konstitusionalisme, Sekjen dan Kepaniteraan Mahkamah Konstitusi RI, Jakarta, 2006 Grafindo Persada, Jakarta, 2011

Pompe dalam P.A.F Lamintang, Hukum Penitentier Indonesia, CV. Armico, Bandung, 1984.

Roeslan Saleh, Masalah Pidana Mati, Aksara Baru, Jakarta, 1978

Sahetapy J.E, Yang Memberi Tauladan Dan Menjaga Nurani Hukum \& Politik, Jakarta, 2007 